\title{
Reconnaissance of chemical and isotopic firn properties on top of Berkner Island, Antarctica
}

\author{
D. WAGENBACH, \\ Institut für Umweltphysik, Universität Heidelberg, D-69120 Heidelberg, Germany \\ W. GRAF, \\ GSF-Forschungszentrum für Umwelt und Gesundheit, Institut für Hydrologie, D-85758 Oberschleissheim, Germany \\ A. Minikin, U. Trefzer, \\ Institut für Umweltphysik, Universität Heidelberg, D-69120 Heidelberg, Germany \\ J. KiPfSTUhl, H. OERTER, \\ Alfred-Wegener-Institut für Polar- und Meeresforschung, D-27515 Bremerhaven, Germany \\ N. BLINDOW \\ Institut für Geophysik, Forschungsstelle für physikalische Glaziologie der Westfälischen Wilhelms-Universitäl Münster, \\ D-48149 Münster, Germany
}

\begin{abstract}
ABSTRAC'I. The ice cap on Berkner Island is grounded on bedrock within the Filchner-Ronne Ice Shelf and is, therefore, expected to bc a well-suited place to retrieve long-term ice-core records reflecting the environmental situation of the Weddell Sea region. Shallow firn cores were drilled to $11 \mathrm{~m}$ at the two main summits of Berkner Island and analysed in high depth resolution for electrical d.c. conductivity (ECM), stable isotopes, chloride, sulphate, nitrate and methane-sulphonate (MSA). From the annual layering of $\delta \mathrm{D}$ and non-sea-salt (nss) sulphate, a mean annual snow accumulation of $26.6 \mathrm{~cm}$ water at the north dome and $17.4 \mathrm{~cm}$ water at the south dome are obtained. As a result of ineffective wind scouring indicated by a relatively low near-surface snow density, regular annual cycles are found for all species at least in the upper 4-5 m. Post-depositional changes are responsible for a substantial decrease of the seasonal $\delta \mathrm{D}$ and nitrate amplitude as well as for considerable migration of the MSA signal opcrating below a depth of $3-4 \mathrm{~m}$. The mean chemical and isotopic firn properties at the south dome corrcspond to the situation on the Filchner-Ronne Ice Shelf at a comparable distance to the coast, whereas the north dome is found to be much more influenced by maritime air masses. Persistent high sea-salt levels in winter snow at Berkner Island heavily obscure the determination of nss sulphate probably due to sulphate fractionation in the Antarctic sea-salt aerosol. Estimated time-scales predict ages at $400 \mathrm{~m}$ depth to be $\sim 2000$ years for the north and $\sim 3000$ years for the south dome. Pleistocene ice is expected in the bottom 200 and $300 \mathrm{~m}$, respectively.
\end{abstract}

\section{INTRODUGTION}

The relatively large Berkner Island, which is grounded on bedrock below sea level within the Filchner Ronne Ice Shelf, constitutes a small-scale ice sheet located adjacent to the Weddell Sea. Due to this specific geographical location and the relatively simple topography, Berkner Island is expected to provide unique long-term ice-core records on the history of this climatically sensitive region. Extensive surveys of Berkner Island by airborne electromagnetic reflection (EMR) and radar altimetry revealed an ice thickness in the order of $900-1000 \mathrm{~m}$ and a summit range with two distinct ice domes, approximately $140 \mathrm{~km}$ apart (Hoppe and Thyssen, 1988).
Generally, the following important clcments of the climatic variability within the Weddell Sea region may be reflected in the icc-core proxy data of its adjacent snow fields (Peel and Mulvaney, 1992):

The mean air temperature and the main source region of water vapour as being recorded by stable isotopes of water $\left(\delta^{18} \mathrm{O}, \delta \mathrm{D}\right)$ and the deuterium excess, respectively.

The overall storminess or cyclonic activity and the mean sea-ice cover possibly indicated by the sea-salt concentration.

The biological productivity to be inferred from the concentration of biogenic sulphate and/or methanesulphonate. 
To obtain the first glacio-chemical and isotopic information on the surface conditions at Berkner Island, shallow firn cores were drilled in 1990 at the north and south domes during the German Filchner-Ronne Ice Shelf expedition (Oerter and others, 1990). Here, we report the depth profiles for chloride (sea salt), nitrate, non-sea-salt (nss) sulphate and methanesulphonic acid (MSA), which were investigated at both sites concurrently with $\delta^{18} \mathrm{O}, \delta \mathrm{D}$ and d.c. ice conductivity (ECM method) in high depth resolution over the first $11 \mathrm{~m}$. Based on this data set, some of the perspectives relevant for future ice-core studies on Berkner Island will be addressed.

\section{METHODS}

The north and south domes of Berkner Island (Fig. 1) were reached in January 1990 by the German Polar 4 aircraft. On both domes, snow sampling was undertaken by $2 \mathrm{~m}$ snow pits and shallow firn-core drillings to a depth of $11 \mathrm{~m}$. The firn temperature was measured directly after termination of the drilling operation by inserting a special PT-100 temperature probe $10-15 \mathrm{~cm}$ into the bottom of the drill hole. Due to logistic constraints, subsequent PT-100 readings could be obtained only over a period of $30 \mathrm{~min}$ at the south dome and over $10 \mathrm{~min}$ at the north dome. Therefore, temperature values obtained are expected to overestimate the real situation slightly and might be regarded as upper limits of the true $10 \mathrm{~m}$ firn temperature.

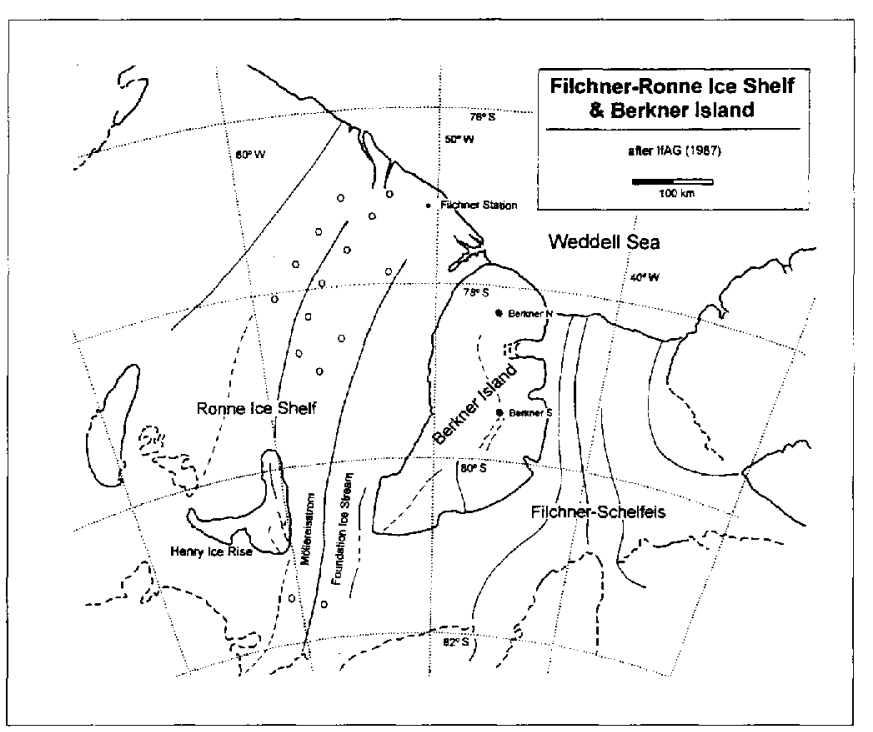

Fig. 1. Map of the Filchner-Ronne Ice Shelf region showing the drill sites at the north and south domes of Berkner Island. Open circles on the ceniral Filchner-Ronne Ice Shelf indicate the positions of shallow firn-core studies similar to the present one (Minikin and others, 1994).

The firn-core processing and analytical procedures for the chemical and isotopic measurements, as well as for the ECM profiling, are identical to those reported in detail by Minikin and others (1994) and Graf and others (1994). The depth resolution for the moltwater analyses was kept within the range of $3-4 \mathrm{~cm}$ to ensure clear identification of the annual layering. The nss sulphate concentrations reported here are deduced from the measured total sulphate and chloride according to Minikin and others (1994), who took into account a factor of 5 depletion of sulphate (relative to sodium) in the coastal Antarctic seasalt aerosol. Chloride was uscd as a sea-water reference, because sodium analyses are presently available only for the north-dome core. In this case, only a slight chloride excess of about $10 \%$ over the chloride to sodium seawater ratio is found. Therefore, no substantial differences are expected by using chloride rather than sodium in calculating nss sulphate concentrations.

\section{RESULTS AND DISCUSSION}

In Figure 2, chemical and isotopic depth profiles arc shown for both ice domes of Berkner Island. To illustrate the stratigraphical pattern at both sites, the continuous depth profiles of the ECM signal, major ions and MSA werc slightly smoothed by a five-point binomial filter to emphasize their seasonal cycles. Prior to this step, the continuous ECM signal was averaged over the corresponding sampling intcrvals used for the meltwater analyses. In the following, we will refer to other chemical and isotopic results which we obtained from the central and eastern Romne Ice Shelf. These data are referenced as Minikin and others (1994) and Graf and others (1994).

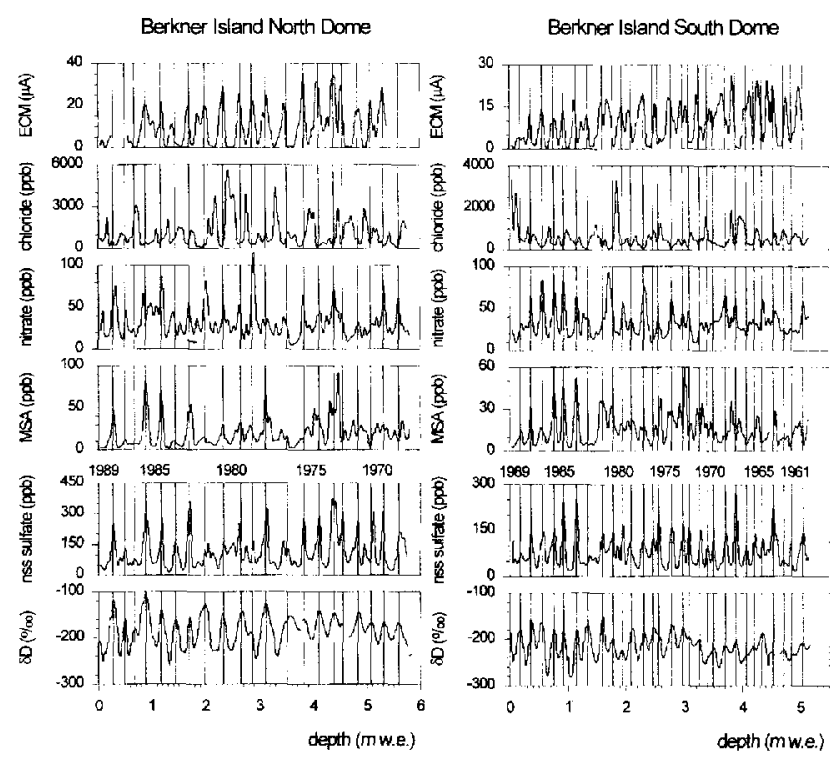

Fig. 2. Profiles of ECM, chemical species and $\delta D$ for the firn cores drilled at the Berkner Island north and south domes. The depth scale is given in water equivalent (w.e.). All records are transformed to equidistant depth intervals (1.5cmw.e.). In addition, the ECM and chemical records are low-pass filtered with a five-point Gaussian filter. Summer horizons according to the year-toyear dating are marked with vertical bars.

\subsection{The depositional regime on Berkner Island}

Our attempt to date precisely the Berkner Island cores by annual-layer counting follows the procedure already applied to shallow firn cores of the contral Filchner- 
Ronne Ice Shelf (Graf and others, 1991). The local summer horizons indicated by the vertical lines in Figure 2 were derived mainly by combining the seasonal cycles of $\delta \mathrm{D}$ and nss sulphate. Whenever possible, supplementary information was then drawn from the other chemical species (as summer maxima of ECM, MSA and nitrate, and winter minima of ECM associated with sea-salt peaks) to reduce the remaining stratigraphical ambiguities. Note, that small deviations between the annual cycles of $\delta \mathrm{D}, \mathrm{ECM}$ and the chemical species may arise from inadequate adjustments of the three individual depth scales.

Based on the working hypothesis that an absolute chronology can be established for the cores by this annual layer-counting method, a net snow accumulation of $26.6 \mathrm{~cm}$ water per year is derived for the north dome, representing the period 1969-89. For the same time interval, a mean annual snow accumulation of only $17.4 \mathrm{~cm}$ water is found at the south dome, which is identical to the overall mean of the whole core of $17.6 \mathrm{~cm}$ water per year covering the period 1961-89. Mean accumulation rates, consistent with the stratigraphical dating method, were obtained for both cores by identifying the thermonuclear tritium $\left({ }^{3} \mathrm{H}\right)$ horizons of the mid and late $1960 \mathrm{~s}$. There is no direct information available on the local representativeness of the net accumulation rates given above. We expect, however, that their local variability is relatively small, since the influence of wind scouring in combination with smallscale surface undulations as related to the bedrock topography) seems to be unimportant on Berkner Island. This is suggested by the surprisingly low snow density in the near-surface layer of around $0.3 \mathrm{Mg} \mathrm{m}^{3}$, indicating that low wind speeds generally prevail. Furthermore, the year-to-year variability of the annual snow accumulation does not exceed 20-25\%, which is rather small and essentially the same as that found on the definitely flat Filchner-Ronne Ice Shelf.

Inspection of the quite regular seasonal cycles of chemical species (as related to the isotope stratigraphy) indicates that both the occurrence of precipitation and the net snow deposition are somewhat homogeneously distributed throughout the year. There is no significant difference in the timing of these cycles (see Fig. 3) compared to what we observed on the Filchner-Ronne Ice Shelf. Despite these relatively favourable depositional conditions, the stratigraphical coherence betwcen both firn cores is obviously weak, even for outstanding depositional events during individual years (except perhaps for the 1980 sea-salt peak and the enhanced biogenic sulphate level around 1973). A special feature, which also holds true on the Filchner-Ronne Ice Shelf, concerns the almost perfect annual layering of chemical and isotopic profiles that appears to be confined to the upper $4-5 \mathrm{~m}$.

To get a rough insight into post-depositional effects operating on longer time-scales, the mean annual cycles of ionic species and $\delta \mathrm{D}$ are calculated for two different sequences centered around 2 and $8 \mathrm{~m}$ depth. The resulting cycles, which are based on the snow calendar already established, are shown in Figure 3 for both drill sites. Postdepositional effects are clearly seen for the isotopic signature, for nitrate and MSA (changes of the chloride

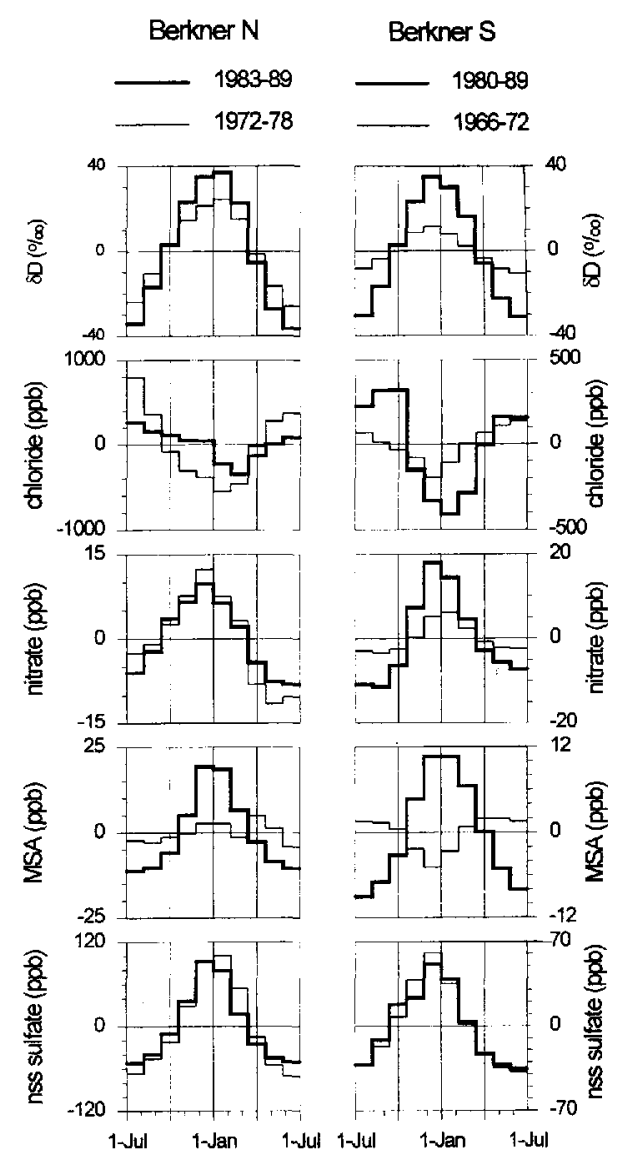

Fig. 3. Mean annual cycles of $\delta D$ and chemical species at the north and at the south domes of Berkner Island as derived for different time spans and depths. The concentration values represent the deviations from the respective long-term means. The thick line is assigned to the near-surface depth interval centered around $2 \mathrm{~m}$, the thin line to the lower depth interval around $8 \mathrm{~m}$.

pattern are mainly due to the episodic occurrence of the sea-salt species).

There is a substantial decrease of the seasonal $\delta \mathrm{D}$ amplitude over the first $5 \mathrm{~m}$ or so, which suggests an efficient mass exchange by water-vapour diffusion on Berkner Island due to the exceptionally low firn density there (Whillans and Grootes, 1985). In particular, at the south dome, nitrate cycles seem to be subject to a similar exchange process (possibly driven by gas-phase $\mathrm{HNO}_{3}$ diffusion) but without a notable net loss over this depth scale. As expected from the higher snow accumulation at the north dome, diffusive smoothing effects are less important. The most obvious change of the chemical stratigraphy is an apparent migration of the MSA summer maxima (defined by the nss sulphate peaks) towards winter layers rather than a diffusive broadening of the peaks. This still unexplained phenomenon was previously observed by Mulvaney and others (1992), but at much greater depths, in an ice core from the Antarctic Peninsula. Of all the species examined, chloride and nss sulphate show the most conservative behaviour on Berkner Island. Consequently, the same is true for the seasonal ECM signal which reflects both the summer maximum of strong acids and the strong sea-salt spikes in winter (leading 
almost to an apparent break-down of the ECM signal during that time).

\subsection{Climatological situation}

To give an overview of the main features in the Berkner Island summit areas, the mean ionic composition and the mean isotopic signature observed over the first $11 \mathrm{~m}$ at the two ice domes are summarized in Table 1, together with the relevant nivological and topographical data. Also included in Table 1 are the typical mean values we observed at positions on the central Filchner-Ronne Ice Shelf at comparable distances from the coast. Although a peer inspection of the latest FMR results would provide some evidence for comparable ice thicknesses at both domes (of $950 \mathrm{~m}$, approximately), we will refer to the values given in Table 1, which we adopted from the contour lines of surface and bedrock elevations given by Hoppe and Thyssen (1988).

The mean isotopic and chemical properties at the south dome show no notable differences from the corresponding positions on the central Filchner-Ronne Ice Shelf, albeit

Table 1. Characterization of the drill sites on the north and south domes of Berkner Island. Uncertainties denote the $(1 \sigma)$ variability of annual means. Numbers in brackets refer to typical values found at positions on the central FilchnerRonne Ice Shelf in comparable distances to the coast

\begin{tabular}{|c|c|c|}
\hline Berkner Island & North dome & South dome \\
\hline \multicolumn{3}{|l|}{ Geographical situation } \\
\hline Position & $78^{\circ} 18^{\prime} \mathrm{S}, 46^{\circ} 17^{\prime} \mathrm{W}$ & $79^{\circ} 36^{\circ} \mathrm{S}, 45^{\circ} 37^{\prime} \mathrm{W}$ \\
\hline Distance to coast $\mathrm{km}$ & $\sim 50$ & $\sim 150$ \\
\hline \multicolumn{2}{|l|}{ Maximum elevation } & 940 \\
\hline lce thickness ${ }^{*}(\mathrm{~m})$ & $\sim 900$ & $\sim 1000$ \\
\hline \multicolumn{3}{|l|}{ Nivological parameters } \\
\hline \multicolumn{3}{|c|}{$10 \mathrm{~m}$ firn temperature $\left({ }^{\circ} \mathrm{C}\right)-22.5^{\dagger}$} \\
\hline \multicolumn{3}{|c|}{ Mean annual snow accumulation } \\
\hline$\left(\mathrm{kg} \mathrm{m}^{-2} \mathrm{a}^{\prime}\right)$ & $\begin{array}{c}226 \pm 53 \\
(200)\end{array}$ & $\begin{array}{l}174 \pm 38 \\
(180)\end{array}$ \\
\hline
\end{tabular}

Mean chemical and isotopic composition

$\begin{array}{lcc}\text { Chloride (ppb) } & 1050 \pm 540 & 570 \pm 390 \\ & (850) & (600) \\ \text { Nitrate (ppb) } & 32 \pm 11 & 34 \pm 9 \\ & (45) & (45) \\ \text { nss sulphate (ppb) } & 112 \pm 38 & 84 \pm 19 \\ & (95) & (85) \\ \text { MSA (ppb) } & 19 \pm 10 & 16 \pm 7 \\ & (19) & (14) \\ \text { SD (\%o) } & -184.2 \pm 13.8 & -216.5 \pm 15.0 \\ & (195) & (210) \\ \text { Deuterium excess (\%o) } & 6.6 \pm 1.5 & 5.5 \pm 1.4\end{array}$

\footnotetext{
* Adopted from Hoppe and Thyssen (1988).

+ Assumed as the upper limit of the true $10 \mathrm{~m}$ firn temperature.
}

there is an altitude difference of roughly $900 \mathrm{~m}$. This is also true for the mean annual snow-accumulation rate and the $10 \mathrm{~m}$ firn temperature. Disregarding the temperature value (which is biased by a positive error), this indicates that both areas are influenced by a common, large-scale airmass regime generating no important altitude effects at the site in question.

The situation at the north dome, however, appears to be outstanding if compared to corresponding positions on the surrounding ice shelf. Among all positions investigated at the Filchner-Ronne Ice Shelf, the highest values of temperature, $\delta \mathrm{D}$, snow-accumulation rate and by far the highest levels of the marine-derived species (nss sulphate, MSA, chloride) are observed at the north dome of Berkner Island. The north dome, therefore, seems to be influenced more directly by the relatively warm and moist maritime air masses. As indicated by the sea-salt inversion (showing a higher level at the elevated sitc), local openwater areas may not substantially contribute to the marine signals observed at this exposed site.

The relatively high sea-salt input on Berkner Island contributes to a serious problem in the nss sulphate determination, which is not simply related to the limited precision of the chemical analyses. For example, if the common procedure to deduce the sea-salt sulphate contribution from measured sodium or chloride concentrations via the sulphate to sodium (chloride) ratio in bulk sea water is applied, consistently negative nss sulphate winter values and as a consequence unrealistic mean nss sulphate levels of $-12 \mathrm{ppb}$ at the north and $19 \mathrm{ppb}$ at the south dome are obtained. As outlined by Minikin and others (1994), a substantial depletion of sulphate relative to sodium or chloride in Antarctic seasalt acrosol has to be taken into account to gain meaningful results (see also section 2).

The overall firn properties on Berkner Island (which more or less agree with those of the surrounding ice shelf can generally be characterized as follows: the deuterium or ${ }^{18} \mathrm{O}$ content, the firn temperature and the snowaccumulation rate all show a picture which is intermediate between the typical inland ice and the true coastal situation, thus reflecting a remnant of continental conditions. The chemical composition, however, is clearly dominated by marine species which overwhelm the Antarctic background level and thus lead to a glaciochemical appearance of this region which is purely maritime.

\subsection{Perspectives for future ice-core studies}

Taking the surface balances found at the north and south domes of Berkner Island as locally representative, an attempt was made to estimate the time-scale covered by deep ice cores at these sites. To do so, we followed the approach of Raymond (1983), who gave on the basis of finite-element modclling an approximate analytical description of the vertical velocity variation with depth at and near a symmetrical icc divide of an ice cap frozen to its horizontal bed. Keeping the age-depth relationship free of too many assumptions, isothermal conditions as well as steady state of the ice cap with respect to surface balance and ice thickness are assumed here.

In Figure 4, the estimated age distributions and the 

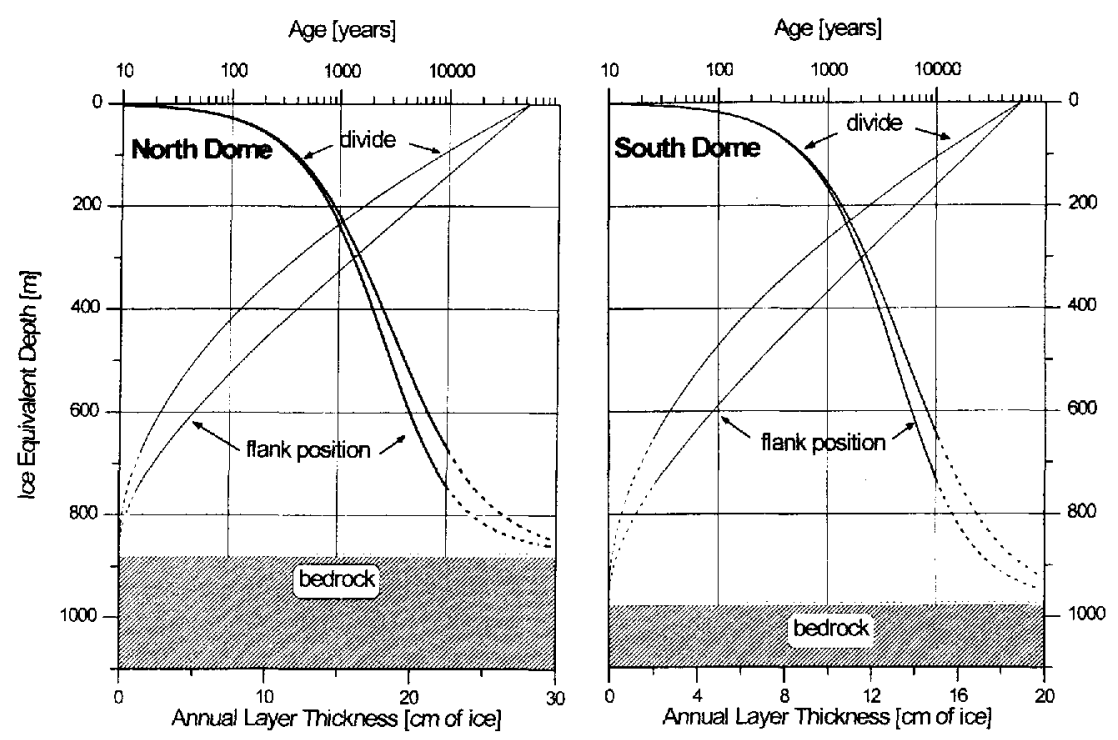

Fig. 4. Estimated depth-age relationship (thick lines) and annual-layer thickness (thin lines) for drill-site positions at and near the firn divide of the north and south domes of Berkner Island.

corresponding annual layer thicknesses are shown for positions at and near (i.e. approximatcly 20 ice thicknesses apart) the ice divide of both main domes of Berkner Island. The same surface balance and ice thickness are used for the divide and slope positions, respcctively. This age estimate suggests that, at both domes, drilling to the bcdrock (which is outside the scope of this paper) will reach glacial-stage ice at comparable depths (i.c. $700 \mathrm{~m}$ at the divide and $780 \mathrm{~m}$ at the slope position). The remaining thickness of Pleistocene ice is predicted to be considerably larger at the divide drill site and may amount there to $200 \mathrm{~m}$ at the north and $300 \mathrm{~m}$ at the south domes of Berkner Island.

In view of the more realistic drillings to intermediate depths, say $400 \mathrm{~m}$, the maximum age reached will be around 2000 years at the north and 3000 years at the south domes with no very large age difference regarding the drill-site position relative to the true ice divide. The corresponding annual-layer thicknesses at these depths are expected to be $9-13 \mathrm{~cm}$ at the north and $7-10 \mathrm{~cm}$ at the south domes with the lower values at the divide position), Especially at the slope positions, this appears to be sufficiently large to resolve preserved annual cycles down to this depth.

Dating of the Berkner Island cores over the time period mentioned above will essentially rely on annual laycr counting (or at least on discontinuous identification of annual cycles) and the unequivocal detection of volcanic reference horizons. Since it appears questionable that the stable-isotope or nitrate cycles will generally survive up to thesc depths (due to diffusive smoothing during firnification and vertical strain), annual-layer counting is to be established in addition by aerosol-related species. In view of the relatively high and regularly varying levels of nss sulphate and sea salt on Berkner Island, a.c. and d.c. conductivity profiling would be most promising in this context (Moore and others, 1992).

For the same reasons, the detection of volcanic horizons via sulphuric acid would be limited to the most prominent events. This is because the winter nss sulphate level is heavily obscured by strong sea-salt inputs, whereas the regularly high summer peak of biogenic sulphate closely coincides with the subsidence of stratospheric aerosol into the lower Antarctic troposphere (as shown by Wagenbach and others, 1988a, b). Indeed, we have not recognized a really clear signal of Agung sulphate at the Berkner Island south dome nor in any firn core from the central FilchnerRonne Ice Shelf. This is also in agrcement with a site in Coats Land (about $500 \mathrm{~km}$ east of Berkner Island), where only an increase in the 1964 winter sulphate level was detected by Mulvaney and Wolff (1993) despite much lower input of sea-salt and biogenic sulphate there. Of the 22 volcanic signals reported by Delmas and others (1992) in their 1000 years chronology from the South Polc, only five events are substantially stronger than the Agung event discussed above. Therefore, only these are expected to serve as a potential dating tool at Berkner Island.

From screening the potential of intermediate-depth ice corcs from Berkner Island to reconstruct the history of environmental changes in the Weddell Sea region, the following conclusions can be drawn:

Due to the favourable surface balance, in view of the $900 \mathrm{~m}$ ice thickness, high-resolution records over some 1000 years are expected.

There are only minor wind-scouring problems and, as, a result, the pronounced and regular annual laycring of sea salt and nss sulphate is preserved which may be used to establish the first ice-core chronology. Checks on the dating by volcanic reference horizons, however, are expected to be restricted to the most prominent events.

The ice-core records will mainly reflect the climatic situation prevailing on the Filchner-Ronne Ice Shelf as well as the aerosol climatology as dominated by the regional source of the marine-derived species sea salt, nss sulphate and MSA.

Specific drawbacks in the interpretation of the biological sulphur records are expected due to post- 
depositional changes in MSA, which are presently not understood. However, more important in this context are the problems arising from the large sea-salt input which leads to an artificial a priori coupling of the seasalt and nss sulphatc records due to a poorly quantified sulphate fractionation of the Antarctic sea-salt acrosol.

\section{ACKNOWLEDGEMENTS}

We thank N. Rädlein for assistance in the field. Part of this study was financially supported by the Deutsche Forschungsgemeinschaft (DFG).

\section{REFERENCES}

Delmas, R. J., S. Kirchner, J. M. Palais and J. R. Petit. 1992. 1000 years of explosive volcanism recorded at the South Pole. Tallus, 448, 335-350.

Graf, $W$. and 6 others. 1991. Isutopic and chemical investigations of $10 \mathrm{~m}$ firn cores from the eastern part of the Ronne Ice Shelf, Antarctica. In Millcr, H. and H. Oerter, eds. Filchner-Ronne-Ice-Shelf-Programme, Report No. 5. Bremerhaven, Alfred Wegener Institute, 45-53.

Graf, W. and 6 others. 1994. Snow-accumulation rates and isotopic content $\left({ }^{2} \mathrm{H},{ }^{3} \mathrm{H}\right)$ of near-surface firn from the Filchner-Ronne Ice Shelf, Antarctica. Ann. Glaciol, 20 (see paper in this volume).

Hoppe, H. and F. Thyssen. 1988. Ice thickness and bedrock elevation in westcrn Neuschwabenland and Berkner Island, Antarctica. Ann. Glaciol., 11, 42-45.
Minikin, A., D. Wagenbach, W. Graf and J. Kipfstuhl. 1994. Spatial and seasonal variations of the snow chemistry at the central Filchner Ronne Ice Shelf, Antarctica. Ann. Glaciol,, 20 (see paper in this volume).

Moore, J. C., E. W. Wolff; H. B. Clausen and C. U. Hammer. 1992. The chemical basis for the electrical stratigraphy of ice. 7. Geophys. Res., 97(B2), 1887-1896.

Mulvancy, R. and E. W. Wolff. 1993. Fvidence for winter/spring denitrification of the stratosphere in the nitrate record of Antarctic firn cores. J. Geophys. Res., 98(D3), 5213-5220.

Mulvaney, R., E. C. Pasteur, D. A. Pcel, E. S. Saltzman and P. -Y. Whung. 1992. The ratio of MSA to non-sea-salt sulphate in Antarctic Peninsula ice cores. Tellus, 44B, 295-303.

Oerter, H. and 6 others. 1990. Glaciological work at Filchnor-Ronne Ice Shelves during the 1989/1990 field season. In Miller, H., ed. FilchnerRonne-Ice-Shelf-Programme, Report Vo. 4. Bremerhaven, Alfred Wegener Institute, $98-103$.

Peel, D. A. and R. Mulvaney. 1992. 'I'ime-trends in the pattern of ocean-atmosphere exchange in an ice core from the Weddell Sea sector of Antarctica. Tellus, 44B, 430-442.

Raymond, C.F. 1983. Deformation in the vicinity of ice divides. $\mathcal{J}$. Glaciol., 29(103), 357-373.

Wagenbach, D., K. O. Münnich, J. Beer and W. Wölfli. 1988a. Time pattern of natural radionuclides in Antarctic aerosol and snow. Chem. Geol, 70(1/2), 105. [Abstract.]

Wagenbach, D., U. Görlach, K. Moser and K. O. Münnich. 1988b. Coastal Antaretic aerosol: the seasonal pattern of its chemical composition and radionuclide content. Tellus, 40B, 426-436.

Whillans, I. M. and P. M. Grootes. 1985. Isotopic diffusion in cold snow and firn. 7. Geophys. Res., 90(D2), 3910-3918.

The accuracy of references in the text and in this list is the responsibility of the authors, to whom queries should be addressed. 